\title{
Current laws could guide assisted death
}

$\mathrm{C}$ anada doesn't have to reinvent the wheel when it comes to regulating physician-assisted death, say some legal and ethics experts.

Lawmakers could provide clarity on thorny issues, including whether children should be eligible, but in most cases the service could be provided under the same rules that already govern other end-of-life decisions.

"It's not as though we'll be left in limbo," says Arthur Schafer, founding director of the Centre for Professional and Applied Ethics at the University of Manitoba. "For at least four decades, doctors have withheld or withdrawn life support at their patients' request ... and I'm not sure that's so dramatically different."

Meanwhile, "there's a very strong reason to discourage delay and a real cost in terms of human suffering," he says.

On Jan. 11, the federal government asked Canada's top court for an extra six months to draft regulations for assisted death, which the court ruled last year should be legal for adults who experience enduring, intolerable suffering from a grievous, irremediable condition. The Supreme Court already suspended its 2015 ruling for 12 months to give governments time to amend laws. That means its decision is slated to take effect on Feb. 6, 2016, unless the extension is granted.

In the Jan. 11 hearing, federal lawyer Robert Frater argued that even with an extension it's possible that "one or more" jurisdictions won't be ready when the Criminal Code ban is lifted. "We're talking about the line between killing and not killing, and Parliament has difficult choices." Counsel for Ontario supported the call for more time, arguing that the provinces carry an "extra burden" in the absence of federal legislation.

But because lawmakers can only expand on the court's decision, counsel for the appellants, Joseph Arvay, said it's not critical to have new laws on the books. "The government seems to think the task ahead is far more complicated than it really is."

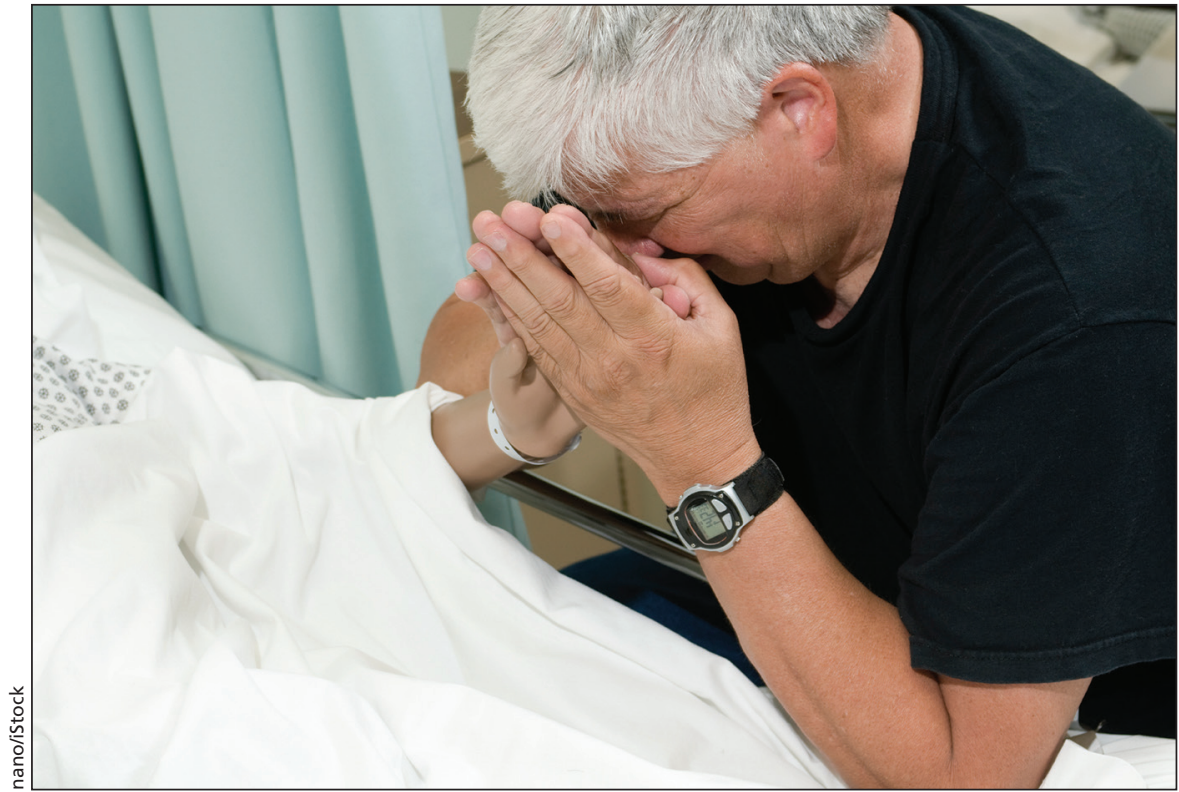

Patients suffering from irremediable illnesses may have to wait six more months before laws are enacted to allow physician-assisted dying.

According to the chair of a provincialterritorial advisory group on physicianassisted death, it's "unrealistic" to require a perfect system in order to offer the service. "We're still going to need to learn through its implementation," says Jennifer Gibson, who is also director of the University of Toronto Joint Centre for Bioethics.

Regulatory colleges and professional associations have already issued a "great deal" of advice that could guide physicians in absence of provincial standards for assisted death, Gibson adds. "It's been remarkable how quickly they mobilized.'

According to David Solomon, a Toronto lawyer who specializes in health industry governance and regulation, provinces are likely to defer to these guidelines anyway, at least "in terms of expectations at the individual physician level."

Following existing consent and capacity laws will help protect doctors from criminal liability, he adds. This involves "communicating all the risks associated with physician-assisted death, including the possibility that it won't work and the possibility of a painful death, and ensuring that the minimum criteria in Carter $v$. Canada is met."

Thorough documentation will also provide a "strong defense to any claims of negligent or wrongful death," as well as claims of discrimination when a doctor refuses to provide the service, Solomon says.

Federal and provincial-territorial guidance is most needed where nonbinding advice conflicts, he notes. "Conscientious objection remains the area where there's the biggest lack of consensus."

Professional regulators and associations, including the Canadian Medical Association and College of Physicians and Surgeons of Ontario, disagree over whether objecting physicians should be compelled to provide referrals for physician-assisted death. There's also conflicting advice on whether publicly funded, faith-based institutions should be required to provide the service.

However, "the issue has been hotly debated before on topics such as therapeutic abortion and the duty of a physician to provide a referral for consultation appears to be settled at the regulatory 
level in Ontario," says Solomon. "I think we can anticipate that similar principles would be applied by the courts."

Another contentious issue is whether governments should impose age restrictions on medical aid in dying. Some provinces, such as Ontario, have mature minor laws that allow people under 18 to make their own medical decisions, which could include requesting assistance to die, says Solomon.
"The test for consent should be the same whether it's for physician-assisted death or any other medical treatment," he explains. However, governments may choose to impose additional restrictions.

Amendments to the Criminal Code may also be necessary to protect health workers who assist doctors to provide medical aid in dying. "On a strict reading of Carter, it only shields physicians," says Solomon. It's unlikely that a police force or court would pursue criminal charges in such cases, "but at the same time it would be helpful for allied health professionals to have more explicit comfort," he says.

The Supreme Court has deferred judgment on whether to delay the legalization of assisted death. - Lauren Vogel, CMAJ

CMAJ 2016. DOI:10.1503/cmaj.109-5222 